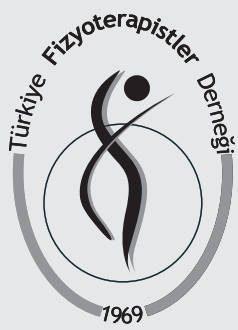

\section{Türk Fizyoterapi ve Rehabilitasyon Dergisi}

$201728(1) 27-32$

Gamze EKiCi

PT, PhD, Assoc. Prof. Şeyda TOPRAK ÇELENAY²

PT, PhD, Asst. Prof.

Öznur BÜYÜKTURAN ${ }^{3}$

PT, PhD, Asst. Prof.

\title{
INVESTIGATION OF THE RISK FACTORS OF DIABETIC NEUROPATHY IN TERMS OF PAIN, SLEEP AND QUALITY OF LIFE
}

\section{RESEARCH ARTICLE}

\section{ABSTRACT}

Purpose: Neuropathy is one of the most common complications of diabetes mellitus and affects the quality of life. The aim of this study was to investigate the risk factors in terms of sleep, pain and quality of life and associated symptoms for diabetic neuropathy.

Methods: Two hundred and seventy-six individuals with diabetes mellitus were included the study, and divided into two groups randomly according to having neuropathy or not. Physical and clinical characteristics were recorded. Pain intensity, social and working life quality, and complaint of non-restorative sleep were assessed by Visual Analogue Scale. The Mann Whitney $\mathrm{U}$ test and independent samples t-test were used to analyze time-dependent changes. Non-time-dependent changes were analyzed by the chi-square test. Logistic regression was done for analyzing the multiple risk factors in the groups.

Results: There were not significant differences between the groups for the following characteristics: age, gender, smoking habit, alcohol consumption, type of diabetes, body mass index $(p>0.05)$. Duration of disease $(p=0.007)$, pain intensity $(p<0.001)$, complaint of non-restorative sleep $(p=0.046)$ were higher, social and working life quality $(p=0.038)$ were lower in neuropathic patients.

Discussion: Duration of disease as a potential risk factor, pain intensity, sleeping complaints and quality of life as the most complained symptoms for diabetic neuropathy should be taken into account for prevention, early detection, and appropriate treatment.

Key Words: Diabetic Neuropathy; Pain; Sleep; Quality of Life

\section{AĞRI, UYKU VE YAŞAM KALITESI AÇISINDAN DIYABETIK NÖROPATI RISK FAKTÖRLERININ INCELENMESi}

Geliş Tarihi: 23.09.2016 (Received) Kabul Tarihi: 24.03.2017 (Accepted)

İletişim (Correspondence):

Gamze EKiCi', PT, PhD, Assoc. Prof., e-mail:fztgamze@yahoo.com Address: Hacettepe University, Faculty of Health Sciences, Department of Occupational Therapy, Samanpazarı, Ankara, Turkey.

Fax: +903123093625

Cell phone: +905323246924

1 Hacettepe University, Faculty of Health Sciences, Department of Occupational Therapy, Ankara, Turkey

2 Yıldırım Beyazıt University, Faculty of Health Sciences, Department of Physiotherapy and Rehabilitation, Ankara, Turkey

3 Ahi Evran University, School of Physical Therapy and Rehabilitation, Kırsehir, Turkey

\section{ARAŞTIRMA MAKALESI}

\section{öz}

Amaç: Nöropati, diyabetes mellitüsün en önemli komplikasyonlarından biridir ve günlük yaşamı etkilemektedir. Bu çalışmanın amacı uyku, ağrı ve yaşam kalitesi ve ilişkili semptomlar aracılığıyla diabetik nöropatinin risk farktörlerini belirlemekti.

Yöntemler: Çalışmaya 276 diyabetes mellitüsü olan birey dahil edildi ve nöropatiye sahip olma veya olmamaya göre rastgele ikiye ayrıldı. Fiziksel ve klinik özellikler kaydedildi. Ağrı yoğunluğu, sosyal ve iş yaşamı kalitesi ve dinlendirici olmayan uyku şikâyeti Görsel Analog Skala ile değerlendirildi. Zaman bağlı değişiklikler analiz etmek için "Mann-Whitney U testi” ve "Bağımsız Örneklem T testi” kullanıldı. Ki-Kare testi ile zamana bağı olmayan değişiklikler analiz edildi. Lojistik regresyon ise gruplar içerisinde birden fazla risk faktörünü analiz etmek için yapıldı.

Sonuçlar: Gruplar arasında takip eden parametreler için istatistiksel olarak anlamlılık bulunmadı; yaş, cinsiyet, sigara içme alışkanlığı, alkol tüketimi, diyabet tipi, beden-kütle indeksi $(p>0,05)$. Nöropatik hastalarda hastalık süresi $(p=0,007)$, ağrı yoğunluğu $(p<0.001)$, dinlendirici olmayan uykudan şikâyet $(p=0.046)$ daha yüksek, sosyal ve iş yaşamı kalitesi $(p=0.038)$ ise daha düşüktü.

Tartışma: Diyabetik nöropati için hastalık süresi potansiyel bir risk faktörüdür; ağrı yoğunluğu, uyku şikâyetleri ve yaşam kalitesi ise koruma, erken teşhis ve uygun tedavi için dikkate alınması gereken çok şikâyet edilen semptomlardır.

Anahtar Kelimeler: Diyabetik Nöropati; Ağrı; Uyku; Yaşam Kalitesi 


\section{INTRODUCTION}

The epidemic of diabetes is a major medical problem of the past century, affecting at least 387 million people worldwide (1). Diabetes Mellitus (DM) has two types of complications: microvascular and macrovascular. One of the most frequently-occurring microvascular complications is Diabetic Neuropathy (DN), of which the most common type is distal symmetrical neuropathy or polyneuropathy. This problem causes significant disability and morbidity (2). Incidences of polyneuropathy have been reported in $10-50 \%$ of patients with DM (3). At the time of diagnosis, neuropathy is present in 10\% of diabetic patients and overall in 50\% of patients with a 25-year history of the disease (4).

Different hypotheses have been proposed to explain the various modes of progression of DN. It has been suggested that risk factors associated with DN include worsening glucose tolerance, older age, longer diabetes duration and cigarette smoking $(5,6)$. Several studies have shown that peripheral neuropathy frequency correlates with duration of DM $(6,7)$. Valensi et al. (1997) demonstrated that age and glycemic control had an effect, and diabetes duration had a major effect on peripheral nerve function (8). The influence of gender on DN has been inconsistent in the literature. Recently, an international study of 2341 patients with type 2 DM were declared that $\mathrm{DN}$ was more common in men, yet a Chinese study including 1524 participants observed the prevalence of DN to be higher in women (9). The roles of drinking alcohol and smoking for DN are also less clear (6). In the literature, findings about risk factors for DN are contradictory. Therefore, it needs to be conducted with different groups.

Moreover, many patients with DN experience neuropathic pain, sleeping disorder, anxiety and depression those affecting quality of life. Pain (the most disturbing symptom) is, typically characterized as burning, tingling, electric, sharp, and shooting which initially starts in both feet and may progress to involve calves, fingers, and hands (stocking and glove pattern) (10). Chronic pain is a subjective experience that affects cognitive and emotional dimensions, impairs mood and thinking (11), causes functional restrictions, and often inhibits daily activities (12) Chronic pain, sleep disturbance, and affective disorders often occur simultaneously (13), and are purported to have multi-directional relations with each other.

The potential risk factors such as duration of disease and the most complained symptoms which could be affect whole life in DM patients with DN should be taken into account to plan more effective interventions. However, there are insufficient number of studies assessing pain intensity, severity of sleep problem, and quality of social and working life in DM patients with DN. Therefore, the aim of this study was to investigate risk factors of $D N$ in terms of pain, sleep and quality of life.

\section{METHODS}

\section{Participants}

The study was carried out at two hundred and seventy-six out-patients with type I and II DM. Patients were eligible for the study if they met the following inclusion criteria: female or male patients, 18 years and over, and volunteered for participating in the study. Patients were excluded from the study if they had a serious or unstable medical or psychological condition. Before their participation, informed consent was obtained from all individual participants included in the study.

This study protocol was approved by the Ethics Committee of Hacettepe University, Faculty of Medicine, Ankara, Turkey and was conducted in accordance with the rules of the Declaration of Helsinki. It was also registered with the clinical trial registry. Written and oral information was given to all patients before testing. All participants gave their informed written consent for participation. The trial was conducted from October 2015 to January 2016 . The patients who were diagnosed by a medical doctor divided into two groups according to having neuropathy (group I: 149 patients) or not (group II: 127 patients) (Figure 1). Diabetic neuropathy is usually tested based on the participants symptoms according to their medical history and a physical exam. The symptoms are pain in hands and/or feet, numbness in extremities, paraesthesia of both feet, cold sensation in the extremities, burning sensation in the extremities, constipation, diarrhea, muscle cramps, fainting, dizziness, urination 


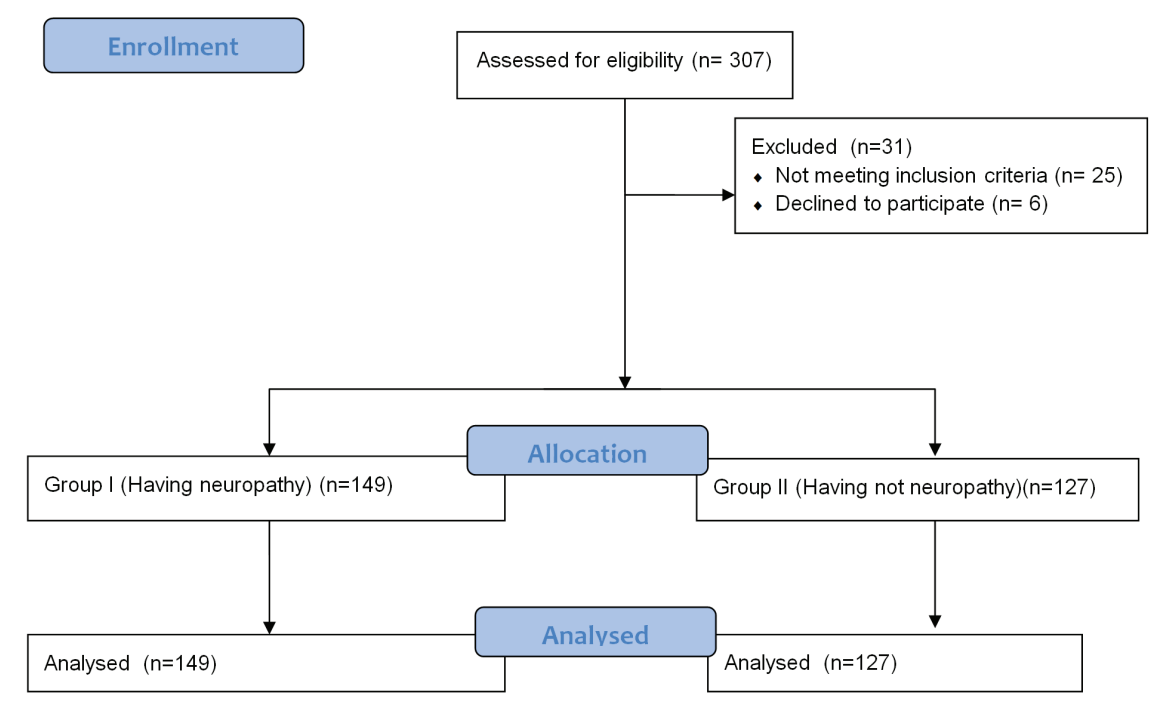

Figure 1: Flow Chart of the Study

difficulties and foot ulceration or nail discoloration. Also, light touch perception was evaluated by the medical doctor using a 10-g Semmes-Weinstein monofilament on 10 different sites on the plantar surface of the foot. If they felt something,the patients were asked to say "now". A foot is called as sensory neuropathy when less than seven sites are felt by the patient. A foot is classified as normal if seven or more sites are felt by the patient (14).

\section{Data Collection and Clinical Measures}

Weight and height of patients were obtained to calculate body mass index (BMI). Age and BMI of the patients were noted as the physical characteristics. To eliminate the effects of using drugs on the study, patients were asked if they were taking medications such as analgesics, myorelaxants, and antidepressants before applying to the study. Gender, type of DM, smoking, alcohol consumption, and duration of disease were recorded and compared between group I and group II.

A Visual analogue Scale (VAS) is a measurement instrument that tries to measure a characteristic or attitude that is believed to range across a continuum of values and can't easily be directed measured. VAS is a simple method for measuring subjective experience. Typically, a VAS consists of a 10 centimeter line anchored at each end by words descriptive of opposing statements or the minimal and maximal extremes of the dimension being measured. VAS has mostly been used in prior studies measuring pain, mood, fatigue, respiration, functional capacity, tension and in the classification of psychiatric patients (15) Furthermore, it has been suggested that VAS has a better responsiveness (i.e. ability to detect clinically significant change) than the Likert scale and might also be more reliable and valid(16). A widely cited article by Onhaus and Adler states that VAS seems to assess more closely what patients actually experience (17).

Moreover, the intensity of pain, complaint of non-restorative sleep, and impact of DN on social and working lives were evaluated by $0-$ to $10-\mathrm{cm}$ VASs. On the VAS, "O" indicated "no pain" and the "10" indicated "the worst imaginable pain" for pain evaluation (15). Complaint of non-restorative sleep was assessed by VAS, in which "0" meant "refreshing sleep" and "10" meant "non-refreshing sleep". Social and working life quality was also assessed by VAS, on which the "O" referred to "no difficulty in social and working lives" and "10" represented "great difficulty in social and working lives". Subjects were asked to mark the point on the VAS that best matched their intensity of complaints.

\section{Statistical Analyses}

SPSS 17.0 for Windows (SPSS Inc. Chicago, IL, USA) was used for statistical analyses. Mean \pm standard deviation (SD) or median (Interquartile Range - IQR) values in 95\% confidence intervals of the investigated data were presented. The "Mann Whitney U test" for non-restorative sleep, and 
social and working life quality or independent samples t-test for age, BMl, duration of disease and pain intensity was used to analyze time-dependent changes of the values. The Chi-square test for gender, type of DM, smoking and alcohol consumption was used to analyze non-time-dependent changes of the values. Logistic regression (18) was used for analyzing the multiple risk factors in the groups. Level of significance was set at $p<0.05$.

\section{RESULTS}

\section{Characteristics of the study patients}

Of the 276 patients, $64.4 \%(n=178)$ were female and $35.6 \%(n=98)$ were male. The means of age and BMI were $61.62 \pm 8.42$ years, and $29.84 \pm 6.52$ $(\mathrm{kg} / \mathrm{m} 2)$; respectively. Physical and clinical characteristics of groups were shown in Table 1. Duration of disease was found a significant difference between the groups $(p=0.007)$.

In the analysis of descriptive findings depending on the gender, type of DM, smoking, alcohol consumption, there was no significant difference between these groups. Table 2 represents descriptive findings of the groups.

\section{Associations of BMI, Duration of disease, Type of DM and Smoking with DN}

Multivariate analysis revealed that duration of disease was found significantly higher in patients with DN on comparison to without DN ( $p<0.001)$. In addition; BMI, type of diabetes and smoking was not found statistically significant $(p=0.063 ; p=0.133$; $p=0.258$, respectively). The multivariate analysis results were shown in Table 3.

The scores of pain intensity, social and working life quality, and complaint of non-restorative sleep for groups were presented in Table 4. There were significant differences in the scores of pain intensity $(p<0.001)$, complaint of non-restorative sleep $(p=0.046)$ and social and working life quality $(p=0.038)$ between the groups.

\section{DISCUSSION}

The present study examined the risk factors for DPN and its symptoms and it revealed that DN was directly associated with duration of diabetes odds of $(\mathrm{AOR}=1.089: 95 \% \mathrm{Cl} ; 1.033-1.147)$. Also pain intensity, complaint of non-restorative sleep for patients with DN were higher than patients without DN, social and working life quality for patients with DN were lower than patients without DN.

DN is a common complication of DM with high morbidity and impairment of quality of life. Tesfaye et al. (1996) study was found that DN was significantly associated with age, duration of disease, height, diastolic blood pressure and smoking status (6). Ashok et al. (2002) showed significant relationships only with age and duration of disease (7). No other association was detected. The results of our study confirmed previous reports regarding the association of neuropathy with duration of disease. Based on the result, it has been very important to examine regularly for detecting and reducing the symptoms of DN and improving quality of life in diabetic patients.

According to Pop-Busui et al. (2009) study included patients with type $2 \mathrm{DM}, 52.6 \%$ of the men had DN compared with $46.2 \%$ of the women (9). Yet, in a Chinese population, $20.7 \%$ of the women and $13.7 \%$ of the men were neuropathic (8). In our study, while the there was no significant difference between genders regarding the presence of DN. Most likely, ethnic and cultural factors may contribute to such differences in gender ratios. However

Table 1: Physical and clinical characteristics of the groups.

\begin{tabular}{|l|c|c|c|}
\hline & $\begin{array}{c}\text { Group I (DN) } \\
(\mathbf{n}=\mathbf{1 4 9 )}\end{array}$ & $\begin{array}{c}\text { Group II (Non-DN) } \\
(\mathbf{n}=\mathbf{1 2 7})\end{array}$ & \multirow{2}{*}{$\mathbf{p}$} \\
\cline { 2 - 3 } & $\mathbf{X} \pm$ SD/Median (IQR) & $\mathbf{X} \pm \mathbf{S D} /$ Median (IQR) & \\
\hline Age (years) & $62.45 \pm 8.72$ & $60.45 \pm 10.42$ & 0.765 \\
\hline BMI (kg/m2) & $29.25 \pm 2.14$ & $30.48 \pm 7.21$ & 0.182 \\
\hline Duration of disease (years) & $11.26 \pm 7.21$ & $8.41 \pm 5.71$ & $0.007^{*}$ \\
\hline
\end{tabular}


the number of women participating to this study is almost two times higher than the number of men.

$\mathrm{DN}$ is a group of disorders and as such the most common chronic complication affecting both type 1 and type 2 diabetic patients (19). Hartemann et al. (2011) study represented that the prevalence of painful DN was about $20 \%$ in patients with type $2 \mathrm{DM}$ and 5\% in those with type 1 (20). However, Jambart et al. (2011) study demonstrated that a significant predictor of DN was presence of type 1 DM (21). In our study, there was no significant difference between DN and types of DM. Our sample would be small to detect such a relationship; therefore further studies including larger groups are needed.

There are relatively few data regarding the influence of smoking and alcohol consumption on DN. In a case-control study, it was shown that the risk for neuropathy was three times higher in smoking type 1 diabetic patients than non-smokers (22). It wasn't found that smoking was not related to neuropathy in type 2 diabetic patients in that study. In another study, in young insulin- treated diabetic patients, it was shown that, apart from glycemic control, cigarette smoking as well as height, and female gender may be independent risk factors for progression of distal sensory neuropathy (23). Adler et al. (1997) also showed that a proportion of neuropathy in diabetic patients was worsened by alcohol consumption (24). According to our result, DN was not significantly related to smoking or alcohol consumption. Most of our patients were non-smokers and non-alcohol consumers, so it was impossible to examine the possible association between neuropathy and smoking, and alcohol consumption critically. Further studies using a randomized clinical trial are needed to evaluate the effects of smoking and alcohol consumption on neuropathy.

Obesity is an index of insulin resistance which may account for poor glycaemic control and predispose to peripheral neuropathy and other complications (25). The increase in the prevalence of polyneuropathy correlated significantly and independently with body weight (26). In the Australian Diabetes Obesity and Lifestyle (AusDiab) study (27), including type II diabetic patients, neither BMI nor waist circumference was identified as risk factors for polyneuropathy in univariate analyses. Our findings indicated that no relationship was found between DN and BMI. The small number of diabetic patients with DN may cause this condition. Thus, further studies including larger groups are needed.

Pain is the most disturbing symptom of DN. The results indicated that patients with DN in our study experienced substantial pain. Thus, our results confirmed what has been documented about the severity of the pain experience among DN patients in other studies $(5,10)$.

Patients with painful DN report substantial interference in sleep, enjoyment of life, recreational activities, normal work, mobility, general activity, social activities, and mood (10) and greater impairment in energy, sleep, physical mobility, and emotional reactions when compared to diabetic and non-diabetic controls (28). Gore et al. found that greater pain levels in DN (mild to moderate to severe) corresponded with higher symptom levels of anxiety and depression; more sleep problems, and lower physical and mental functioning (29). The results of our study confirmed previous reports regarding the negative impacts of DN on the social and working life quality.

Patients with painful DN experience nocturnal exacerbations due to pain $(10,30)$. The potential impact of these exacerbations on the various dimensions of sleep is, however, unknown. Further, DM itself can adversely affect sleep (31). Several studies were found that the patients with DN had more sleep problems than patients without DN (28). Our findings were also similar this results.

Our limitations for this study were sample size and homogeneity. Larger and more homogenous groups are needed to determine relationships between variables. Although the evaluations which were taken by VAS were valid and reliable, the instruments specially developed for DM could be used in the future studies. Participants' age range is high. Also the duration of disease between groups can affect the results.

In conclusion, duration of disease as a potential risk factor, pain intensity, sleeping complaints and quality of life as one of the most complained symptoms for DN should be taken into account for 
prevention, early detection, and appropriate treatment. Properly planned intervention approaches are needed to cope with the symptoms of DN, an important problem in DM and affecting the individual's life. The results of this study may be indicative for intervention plans. However there is a need for further evidence-based studies which include more homogeneous and broader groups.

\section{REFERENCES}

1. O'Brien PD, Hur J, Robell NJ, Hayes JM, Sakowski SA, Feldman EL. Gender-specific differences in diabetic neuropathy in BTBR ob/ ob mice. J Diabetes Complications 2016;30(1):30-7.

2. Salvotelli L, Stoico V, Perrone F, Cacciatori V, Negri C, Brangani C, et al. Prevelance of neuropathy in type 2 diabetic patients and its association with other diabetes complications: The Verona Diabetic Foot Screening Program. J Diabetes Complications. 2015; 29(8):1066-70.

3. Dyck PJ, Thomas PK. Diabetic Neuropathy 2nd ed. WB Saunders: Philadelphia; 1999.

4. Feldman EL, Russell JW, Sullivan KA, Golovoy D. New insights into the pathogenesis of diabetic neuropathy. Curr Opin Neurol. 1999;12(5):553-63.

5. Schmader KE. Epidemiology and impact on quality of life of postherpetic neuralgia and painful diabetic neuropathy. Clin J Pain. 2002;18(6):350-4.

6. Tesfaye S, Stevens LK, Stephenson JM, Fuller JH, Plate M, Ionescu-Tirgoviste $\mathrm{C}$, et al. Prevalence of diabetic peripheral neuropathy and its relation to glycemic control and potential risk factors. The EURODIAB IDDM complications study. Diabetologia. 1996;39(11):1377-84.

7. Ashok S, Ramu M, Deepa R, Mohan V. Prevalence of neuropathy in type 2 diabetic patients attending a diabetes centre in South India. J Assoc Physicians India. 2002;50:546-50.

8. Valensi P, Giroux C, Seeboth-Ghalayini B, Attali JR. Diabetic peripheral neuropathy: Effects of age, duration of diabetes, glycemic control, and vascular factors. J Diabetes Complications. 1997;11(1):27-34.

9. Pop-Busui R, Lu J, Lopes N, Jones TL, BARI 2D Investigators. Prevalence of diabetic peripheral neuropathy and relation to glycemic control therapies at baseline in the BARI 2D cohort. J Peripher Nerv Syst.2009;14(1):1-13.

10. Galer BS, Gianas A, Jensen MP. Painful diabetic polyneuropathy: epidemiology, pain description, and quality of life. Diabetes Res Clin Pract . 2000;47(2):123-8.

11. Sator-Katzenschlager SM, Schiesser AW, Kozek-Langenecker SA, Benetka G, Langer G, Kress HG. Does pain relief improve pain behavior and mood in chronic pain patients? Anesth Analg 2003;97(3):791-7.

12. Becker N, Thomsen Bondegaard A, Olsen Kornelius A, Sjøgren P, Bech P, Eriksen J. Pain epidemiology and health related quality of life in chronic non-malignant pain patients referred to a Danish multidisciplinary pain center. Pain. 1997;73(3):393-400.

13. Wilson KG, Eriksson MY, D'Eon JL, Mikail SF, Emery PC. Major depression and insomnia in chronic pain. Clin J Pain. 2002;18(2):77-
83.

14. Nather A, Neo SH, Chionh SB, Liew SC, Sim EY, Chew JL. Assessment of sensory neuropathy in diabetic patients without diabetic foot problems. J Diabetes Complications. 2008;22(2):126-31.

15. Hasson D, Arnetz BB. Validation and Findings Comparing VAS vs. Likert Scales for Psychosocial Measurements. Int Electron J Health Educ, 2005;8:178-192.

16. Vickers AJ. Comparison of an ordinal and a continuous outcome measure of muscle soreness. Int J Technol Assess Health Care Fall 1999;15(4):709-16.

17. Ohnhaus EE, Adler R. Methodological problems in the measurement of pain: acomparison between the verbal rating scale and the visual analogue scale. Pain. 1975;1(4):379 -84.

18. Harrell F. Regression modelling strategies with applications to linear models, logistic regression, and survival analysis. New York: Spinger-Varlag New York, Inc; 2001;53-85.

19. Sima AA. New insights into the metabolic and molecular basis for diabetic neuropathy. Cell Mol Life Sci. 2003; 60(11):2445-64.

20. Hartemann A, Attal N, Bouhassira D, Dumont I, Gin H, Jeanne S, et al. Painful diabetic neuropathy: Diagnosis and management. Diabetes Metab. 2011;37(5):377-88.

21. Jambart S, Ammache Z, Haddad F, Younes A, Hassoun A, Abdalla $\mathrm{K}$, et al. Prevalence of painful diabetic peripheral neuropathy among patients with diabetes mellitus in the Middle East region. J Int Med Res. 2011;39(2):366-77.

22. Mitchell BD, Hawthorne VM, Vinik Al. Cigarette smoking and neuropathy in diabetic patients. Diabetes Care. 1990;13(4):43437.

23. Christen WG, Manson JE, Bubes V, Glynnf RJ. Risk factors for progression of distal symmetric polyneuropathy in type 1 diabetes mellitus. Sorbinil Retinopathy Trial Research Group. Am J Epidemiol . 1999;150(11):1142-51.

24. Adler Al, Boyko EJ, Ahroni JH, Stensel V, Forsberg RC, Smith DG. Risk factors for diabetic peripheral sensory neuropathy. Results of the Seattle prospective diabetic foot study. Diabetes Care. 1997;20(7):1162-7.

25. Solomon OU, Mayowa OO, Tokunbo AU, Fabian HP, Godwins OE, Adesola O. The association between Body Mass Index and Diabetic Peripheral Neuropathy. Hung Med J. 2008; 2(1): 63-8.

26. Tomic' M, Poljičanin T, Pavlic'-Renar I, Metelko Z. Obesity - a risk factor for microvascular and neuropathic complications in diabetes? Diabetologia Croatica. 2003;32(2):73-8.

27. Tapp RJ, Shaw JE, de Courten MP, Dunstan DW, Welborn TA, Zimmet PZ: Aus-Diab Study Group. Foot complications in type 2 diabetes: an Australian population based study. Diabet Med. 2003;20(2):105-13.

28. Benbow SJ, Wallymahmed ME, MacFarlane IA. Pain severity in diabetic peripheral neuropathy is associated with patient functioning, symptom levels of anxiety and depression, and sleep. J Pain Symptom Manage. 1998;30(4):374-85.

29. Gore M, Brandenburg NA, Dukes E, Hoffman DL, Tai KS, Stacey B. Pain severity in diabetic peripheral neuropathy is associated with patient functioning, symptom levels of anxiety and depression, and sleep. J Pain Symptom Manage. 2005;30(4):374-85

30. Benbow SJ, MacFarlane IA. Painful diabetic neuropathy. Baillière's best practice \& research. Clin Endocrinol Metabol. 1999;13(2):295-308.

31. Sridhar GR, Madhu K. Prevalence of sleep disturbances in diabetes mellitus. Diabetes Res Clin Prac . 1994; 23(3):183-6. 